\title{
ANÁLISE DA QUALIDADE DE ÁGUA DO CÓRREGO DOS CESÁRIOS ANÁPOLIS/GO
}

\section{Cristiane Aparecida de Oliveira ${ }^{1}$ Wellington França Barcelo Jéssica de Sá Guimarães Peixoto ${ }^{3}$}

Resumo: A água é fundamental à manutenção da vida e sua qualidade depende das condições naturais e da ocupação do solo na bacia hidrográfica. Ela contém, geralmente, diversos componentes, que provêm do próprio ambiente natural ou foram introduzidos a partir de atividades humanas. Para caracterizar uma água, são determinados diversos parâmetros, os quais representam as suas características físicas, químicas e biológicas. Esses parâmetros são indicadores da qualidade da água e constituem impurezas quando alcançam valores superiores aos estabelecidos para determinado uso. Este trabalho teve como objetivo avaliar a qualidade físico-química da água do córrego dos Cesários - Anápolis/GO e sua capacidade de dissolução de contaminantes. O citado córrego recebe um resíduo proveniente da lavagem de filtros de uma Estação de Tratamento de Água (ETA). Esse resíduo deságua no córrego sem nenhum tratamento prévio. As análises foram realizadas no Laboratório de Geoquímica da Universidade de Brasília. Os parâmetros avaliados foram pH, Condutividade Elétrica (Ce), Ca (Cálcio), Mg (Magnésio), $\mathrm{Na}$ (Sódio), $\mathrm{K}$ (Potássio), $\mathrm{NH}_{3}$ (Nitrito), $\mathrm{F}$ (Flúor), $\mathrm{Cl}$ (Cloro), $\mathrm{NO}_{3}$ (Nitrato), $\mathrm{PO}_{4}$ (Fosfato), $\mathrm{SO}_{4}$ (Sulfato), Alcalinidade, Fe (Ferro), Si (Silício) e Alumínio (Al). De acordo com a caracterização físico-química efetuada nesse trabalho, pode-se dizer que a qualidade da água do Córrego dos Cesários precisa ser melhorada e devem ser tomadas as devidas providências para evitar que continue o despejo de resíduos, tanto por parte da ETA de Anápolis quanto por esgotos domésticos que margeiam seu curso. Caso contrário, as alterações na classe do rio podem trazer prejuízos não só ao meio ambiente, mas também à saúde pública da população em geral.

Palavras-Chave - Caracterização. Contaminantes. Efluente.

\footnotetext{
${ }^{1}$ Licenciada em Matemática e Especialização em Ensino da Matemática pela Universidade Estadual de Goiás, Tecnólogo em Gestão Ambiental - Faculdade Católica de Anápolis/GO e Mestranda em Geociências Aplicadas, UnB. E-mail: cris.gestorambiental@gmail.com

${ }^{2}$ Tecnólogo em Gestão Ambiental pela Faculdade Católica de Anápolis, FCA. E-mail: wfb@dr.com

${ }^{3}$ Bióloga pela Universidade Federal de Goiás e Mestranda em Geociências Aplicadas, UnB. E-mail: jessica guimaraes15@hotmail.com
} 


\section{1 - INTRODUÇÃO}

A qualidade da água está associada a uma série de fatores que dependem de diferentes componentes que se fazem presentes na composição da água. Dizer se a água é boa para o consumo ou está contaminada não é algo simples, devem ser analisadas as

condições naturais, a formação geológica da área e as atividades humanas desenvolvidas in loco. Uma das maneiras de verificar a qualidade da água seja para controle, preservação ou monitoramento, é a utilização dos Índices de Qualidade de Água (IQA). Shinma (2004), é categórico ao afirmar "[...] com o intuito de facilitar a interpretação das informações de qualidade de água de forma abrangente e útil, para especialistas ou não, é fundamental a utilização de índices de qualidade".

Em vista que, a qualidade desejável da água é em função do seu uso previsto existe uma política normativa nacional de uso da água. Os teores máximos de impurezas permitidos na água constituem os padrões de qualidade com o objetivo de garantir que a água a ser utilizada para um determinado fim não contenha impurezas que venham a prejudicá-lo. As concentrações limites toleráveis significam que a substância, se ingerida por um indivíduo com constituição física mediana, em certa quantidade diária, durante um determinado período de vida, adicionada à exposição esperada da mesma substância por outros meios (alimento, ar, etc.), submete esse indivíduo a um risco inaceitável de acometimento por uma enfermidade crônica resultante.

Uma forma de definir a qualidade das águas dos mananciais é enquadrá-los em classes, em função dos usos propostos para os mesmos, estabelecendo-se critérios ou condições a serem atendidos. No Brasil, essa classificação foi definida pela Resolução $n^{\circ}$ 357, de 17 de março de 2005, do Conselho Nacional do Meio Ambiente. "Esta Resolução dispõe sobre a classificação e diretrizes ambientais para o enquadramento dos corpos de água superficiais, bem como estabelece as condições e padrões de lançamento de efluentes" (CONAMA, 2005).

Para avaliação da qualidade da água devem ser analisados fatores físicos, químicos e biológicos. Quanto à qualidade física, a estratégia principal consiste na 
identificação de parâmetros que representem, de forma indireta, a concentração de sólidos - em suspensão ou dissolvidos - na água. Por um lado, revelam a qualidade estética da água, por outro, águas com elevado conteúdo de sólidos comprometem a eficiência da desinfecção, ou seja, nesse caso sólidos podem se mostrar associados à presença de microorganismos.

Já a qualidade química é aferida pela própria identificação do componente na água, por meio de métodos laboratoriais específicos. Tais componentes químicos não devem estar presentes na massa líquida acima de certas concentrações determinadas com o auxílio de estudos epidemiológicos e toxicológicos.

A avaliação da qualidade microbiológica da água tem um papel destacado no processo em vista do elevado número e da grande diversidade de microorganismos patogênicos que pode estar presente nela. No entanto, determinar a presença de diferentes microorganismos e sua quantidade tornaria o procedimento muito complexo e até inviável, porque envolveria a preparação de diferentes meios de culturas. $\mathrm{Na}$ realidade, utilizam-se organismos que são facilmente identificáveis e cuja ocorrência pode ser de origem patogênica como, por exemplo, as bactérias coliformes, sendo assim chamadas de organismos indicadores. O Ministério da Saúde em sua obra "Vigilância e controle da qualidade da água para consumo humano" (2006) a respeito do tema destaca que:

\begin{abstract}
Uma grande vantagem no uso de bactérias coliformes como indicadoras de contaminação fecal é sua presença em grandes quantidades nos esgotos domésticos, já que cada pessoa elimina bilhões dessas bactérias diariamente. Dessa forma, havendo contaminação da água por esgotos domésticos, é muito grande a chance de se encontrar coliformes em qualquer parte e em qualquer amostra de água, o que não acontece, por exemplo, no caso de metais pesados, que se diluem bastante na massa líquida e muitas vezes não são detectados nas análises de laboratório. Além disso, a identificação de coliformes é feita facilmente, já que as bactérias pertencentes a esse grupo fermentam a lactose do meio de cultura, produzindo gases que são observados nos tubos de ensaio.
\end{abstract}

As características físicas, químicas e biológicas da água estão associadas a uma série de processos que ocorrem no corpo hídrico e em sua bacia de drenagem. A capacidade de dissolução e a capacidade de transporte são algumas delas. As substâncias dissolvidas e as partículas presentes no seio da massa líquida são 
transportadas pelos cursos d'água, mudando continuamente de posição e estabelecendo um caráter fortemente dinâmico para a questão da qualidade da água.

Assim como os processos naturais, as atividades humanas, respaldadas em um estilo de vida e desenvolvimento, têm determinado alterações significativas no meio ambiente, influenciando a qualidade desse recurso.

A qualidade da água é afetada por mudanças em teores de nutrientes, sedimentos, temperatura, $\mathrm{pH}$, metais pesados, toxinas não metálicas, componentes orgânicos persistentes e agrotóxicos, fatores biológicos, entre muitos outros (CARR E NEARY, 2008). Os processos de urbanização, de industrialização e de produção agrícola não têm levado em conta a capacidade de suporte dos ecossistemas (REBOUÇAS, 1997). Para este autor,

[...] Este quadro está sensivelmente associado ao lançamento - deliberado ou não - de mais de $90 \%$ dos esgotos domésticos e cerca de $70 \%$ dos efluentes industriais não tratados, o que tem gerado a poluição dos corpos de água doce de superfície em níveis nunca antes imaginados (REBOUÇAS, 1997, p. 6).

A qualidade da água em determinado ponto de um rio é produto da qualidade da água em um ponto anterior modificada por diversos fatores atuantes no trecho que separa os pontos. Estes fatores podem ser características físicas e geomorfologicas do leito do rio, misturas da água com qualidades diferentes, presença de vegetação ciliar, regime climático, presença de comunidades e pelas interferências antrópicas (SÉ, 1992; ARCOVA E CICCO, 1999; ANIDO, 2002). Assim esse trabalho tem por objetivo avaliar a qualidade físico-química da água do Córrego dos Cesários situado na cidade de Anápolis/GO cujo corpo receptor tem sido utilizado como descarga de resíduos provenientes da lavagem de filtros da Estação de Tratamento de Água e também por diversas redes de esgotos marginais ao seu curso d'água.

\section{2 - DESENVOLVIMENTO}

\section{1 - Localização da área de Estudo: Córrego dos Cesários - Anápolis, Goiás}

O Córrego dos Cesários tem sua nascente no Bairro Alexandrina da cidade de Anápolis e percorre diversos bairros até chegar à foz do Rio Antas. Próximo a uma de 
suas nascentes é realizada a descarga de resíduos oriundos da Estação de Tratamento de Água de Anápolis provenientes da lavagem de filtros da referida ETA. (Figura 1)

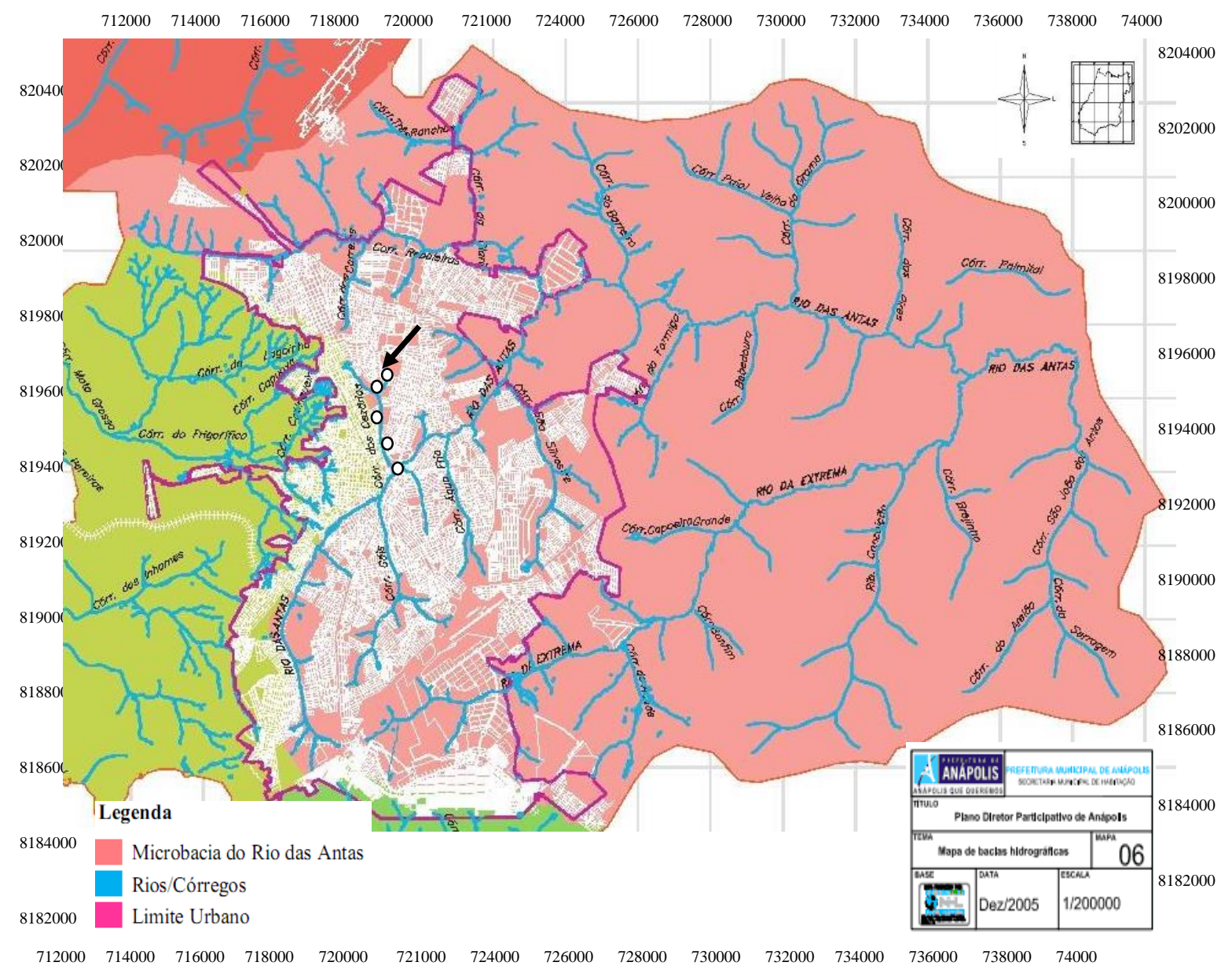

Figura 1- Local de descarte do resíduo da Estação de Tratamento (seta) e Pontos Coletas das amostras de Água no Córrego dos Cesários- Anápolis/GO

2.2 - Coletas e amostras

Foram coletadas cinco amostras em diferentes pontos assim distribuídos: Coleta 1: Nascente do Córrego dos Cesários, Coleta 2: Local de despejo dos resíduos da água de lavagem dos filtros da ETA, Coleta 3: Encontro da Nascente que recebeu o efluente com outra nascente do mesmo Córrego, Coleta 4: Curso do Córrego dos Cesários situado no Bairro Araujoville, Coleta 5: deságue do Córrego dos Cesários com o Rio das Antas.

\section{3 - Análises Laboratoriais}


As análises das amostras foram realizadas pelo Laboratório de Geoquímica da Universidade de Brasília logo após a recepção das mesmas.

Todas as metodologias utilizadas nas análises químicas foram baseadas no Standard Methods for the Examination of Water and Wastewater; edição da American Public Health Association (APHA), da American Water Works Association (AWWA), e da Water Pollution Control Federation (WPCF).

Para análise de sódio $(589,00 \mathrm{~nm})$ e potássio $(766,49 \mathrm{~nm})$ foi utilizado o Espectrofotômetro de Absorção Atômica (EAA), da marca Perkin Elmer, modelo Aanalyst 200. Como fonte de excitação foi utilizada chama de ar-acetileno.

As análises de cálcio $(317,93 \mathrm{~nm})$, magnésio $(279,88 \mathrm{~nm})$, ferro $(259,95 \mathrm{~nm})$, silício (251,61 nm), alumínio $(308,21 \mathrm{~nm})$, foram realizadas no Espectrômetro de Emissão Atômica com Plasma indutivamente acoplado (ICP/AES) marca PERKIN ELMER, modelo Spectroflame-Fvmo3, utilizando nebulizador Meinhard (Figura 2).

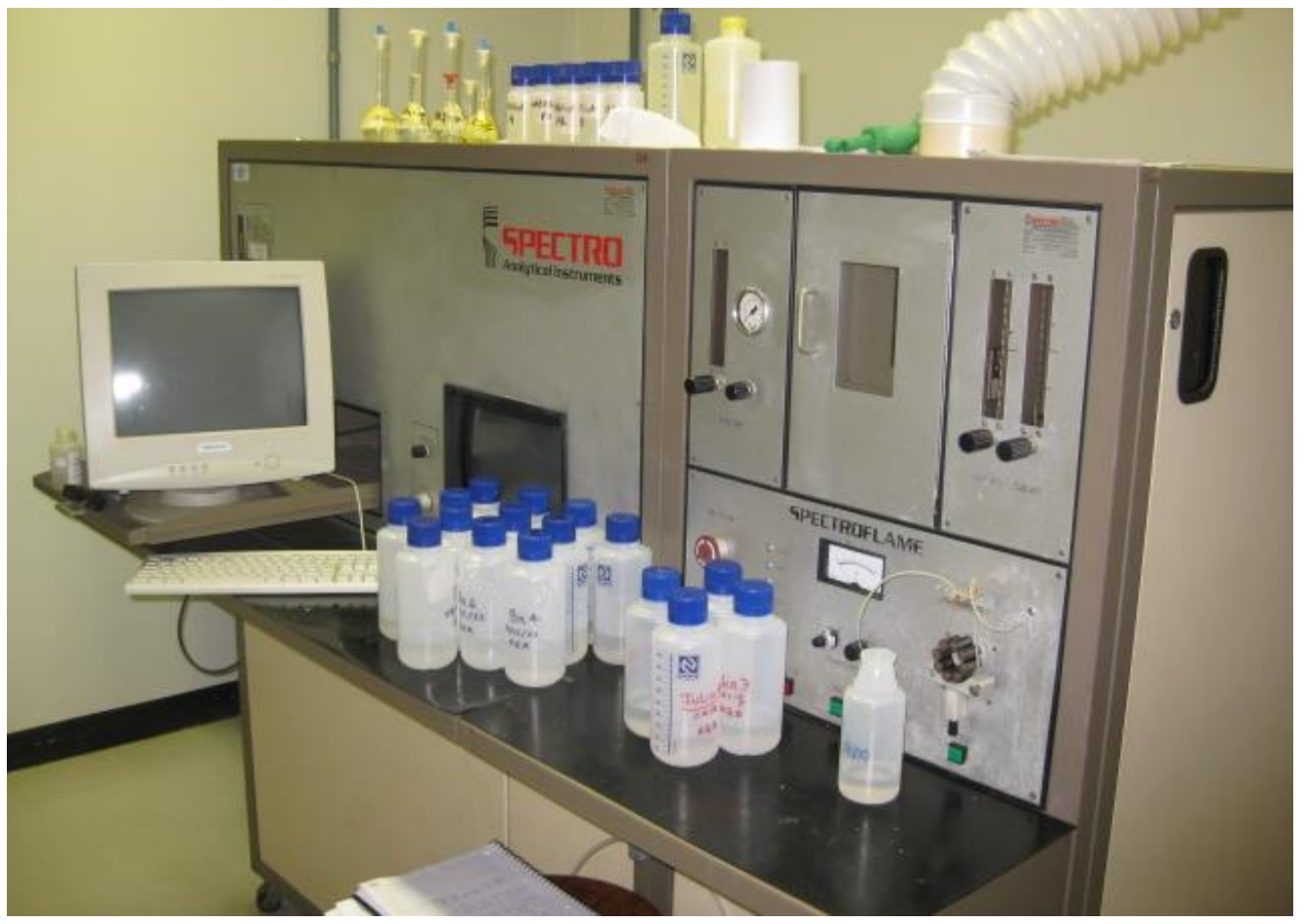

Figura 2 - Detalhe de equipamento de análise laboratorial - ICP/AES.

Os ânions flúor, cloro nitrato, fosfato e sulfato foram determinados por cromatógrafo iônico (IC) com condutividade suprimida da marca Dionex, modelo ICS90. A alcalinidade foi determinada por método titulométrico de análise com $\mathrm{H}_{2} \mathrm{SO}_{4} 0,02 \mathrm{~N}$ padronizado com $\mathrm{NaOH} 0,05 \mathrm{~N}$, utilizando um titulador automático da marca Schott, modelo Titroline easy. 
As curvas de calibração do EAA, ICP e IC foram preparadas com soluções padrões de 1000 ppm da marca Vetec e, a partir delas, foram feitas as diluições necessárias para cada elemento. Determinou-se o pH e a condutividade utilizando um multiparâmetro portátil da Hach, série Sension.

\section{4 - Resultados das análises}

As análises das águas obtidas por meio das coletas realizadas na nascente e ao longo do leito do Córrego dos Cesários revelaram algumas características que são importantes na tomada de decisão quanto à necessidade de qualquer processo corretivo referente aos problemas encontrados em sua nascente e em toda a sua extensão.

A qualidade da água tem sido comprometida desde o manancial pelo lançamento de efluentes e resíduos, o que exige investimento nas estações de tratamento e alterações na dosagem de produtos para se garantir a qualidade da água na saída das estações.

\subsection{1- $\mathrm{pH}$}

O potencial hidrogêniônico $(\mathrm{pH})$ parâmetro químico que representa a intensidade das condições ácidas ou alcalinas do meio líquido por meio da medição da presença de íons hidrogênio $\left(\mathrm{H}^{+}\right)$influi na distribuição das formas livre e ionizada de diversos compostos químicos, além de contribuir para um maior ou menor grau de solubilidade das substâncias e de definir o potencial de toxicidade de vários elementos.

A variável $\mathrm{pH}$ do Córrego estudado apresentou um comportamento semelhante em todos os pontos amostrados com valores entre 6,0 a 9,0 exceto na nascente que foi de 4,87 (Figura 3). As análises comprovaram que os valores de pH encontram-se dentro dos padrões exigidos pela resolução CONAMA 357/2005 a qual não deve ultrapassar os limites de 6,0 a 9,0. 


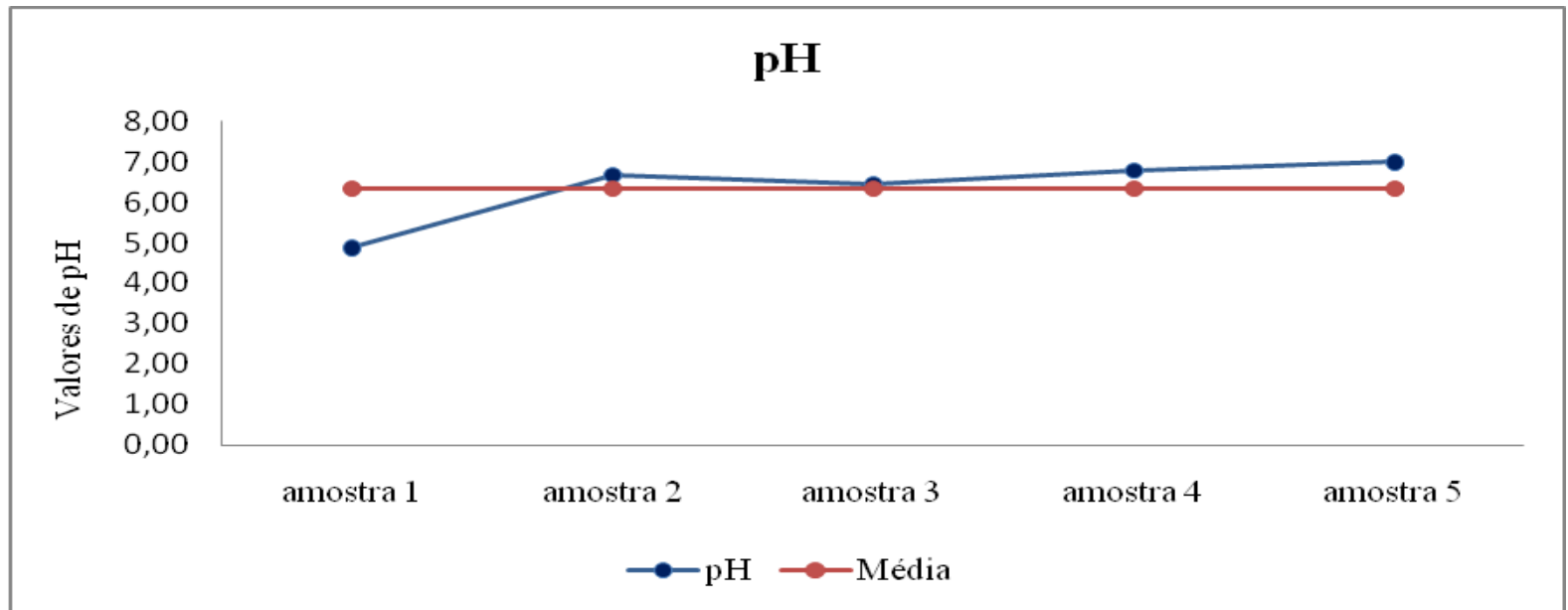

Figura 3 - Valores médios de pH obtidos nas análises da água do Córrego João Cesário Anápolis/GO

\subsection{2 - Condutividade Elétrica (Ce)}

Os valores referentes à condutividade elétrica do córrego em estudo foram inferiores a $50 \mu \mathrm{S} \mathrm{cm}^{-1}$ (Figura 4), podendo ser classificados como baixos. Sendo que, apenas a amostra coletada no ponto 5 apresentou valor médio de $173,40 \mu \mathrm{S} \mathrm{cm}^{-1}$ indicando uma modificação na composição da água, especialmente na sua concentração mineral. A provável causa se deve à influencia dos resíduos recebidos pelo lançamento da água de lavagem de filtro da ETA em sua nascente e acumulados de materiais poluentes jogados pela população por meio de esgotos domésticos. Segundo a CETESB, 2007, "em geral, níveis superiores a $100 \mu \mathrm{S} \mathrm{cm}{ }^{-1}$ indicam ambientes impactados" Conforme Silva (2010) "O parâmetro condutividade elétrica [...] pode contribuir para possíveis reconhecimentos de impactos ambientais que ocorram na bacia de drenagem ocasionados por lançamentos de resíduos industriais, mineração, esgotos, etc. [...]".

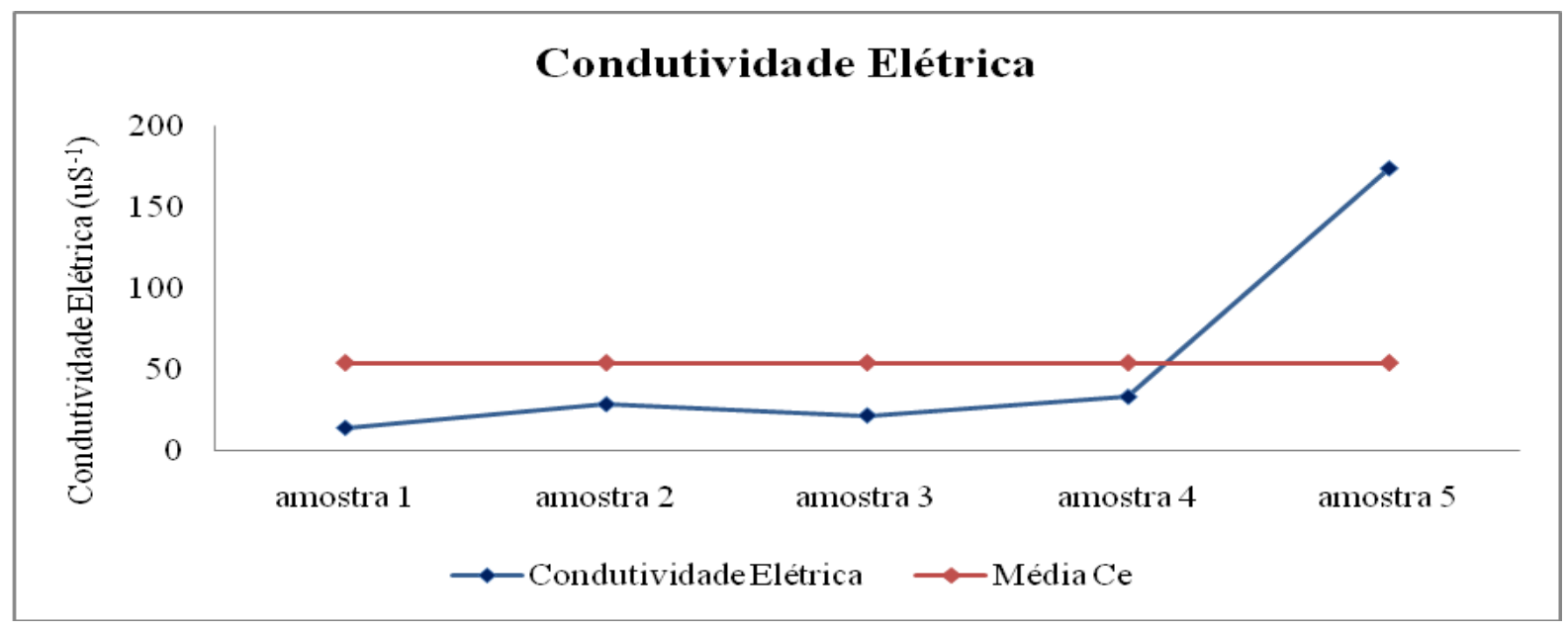


Figura 4 - Valores médios de Condutividade Elétrica obtidos nas análises da água do Córrego João Cesário Anápolis/GO

\subsection{3 - Alcalinidade}

A alcalinidade indica a quantidade de íons na água que reagem para neutralizar os íons de hidrogênio. Constitui, portanto, uma medição da capacidade da água de neutralizar os ácidos, servindo assim para expressar a capacidade de tamponamento, isto é, sua condição de resistir a mudanças do pH. Verifica-se assim que, na maior parte dos ambientes aquáticos, a alcalinidade deve-se exclusivamente à presença de bicarbonatos (pH entre 4,4 e 8,3).

Valores elevados de alcalinidade estão associados a processos de decomposição da matéria orgânica e à alta taxa respiratória de microorganismos, com liberação e dissolução do gás carbônico $\left(\mathrm{CO}_{2}\right)$ na água. $\mathrm{A}$ alcalinidade das águas associa-se à dureza. Quanto a este parâmetro, nota-se um elevado valor apenas na amostra de número 5 que é de $64,81 \mathrm{mg} \mathrm{L}^{-1}$, verificando assim que a água desse córrego pode ser considerada como água mole (Figura 5).

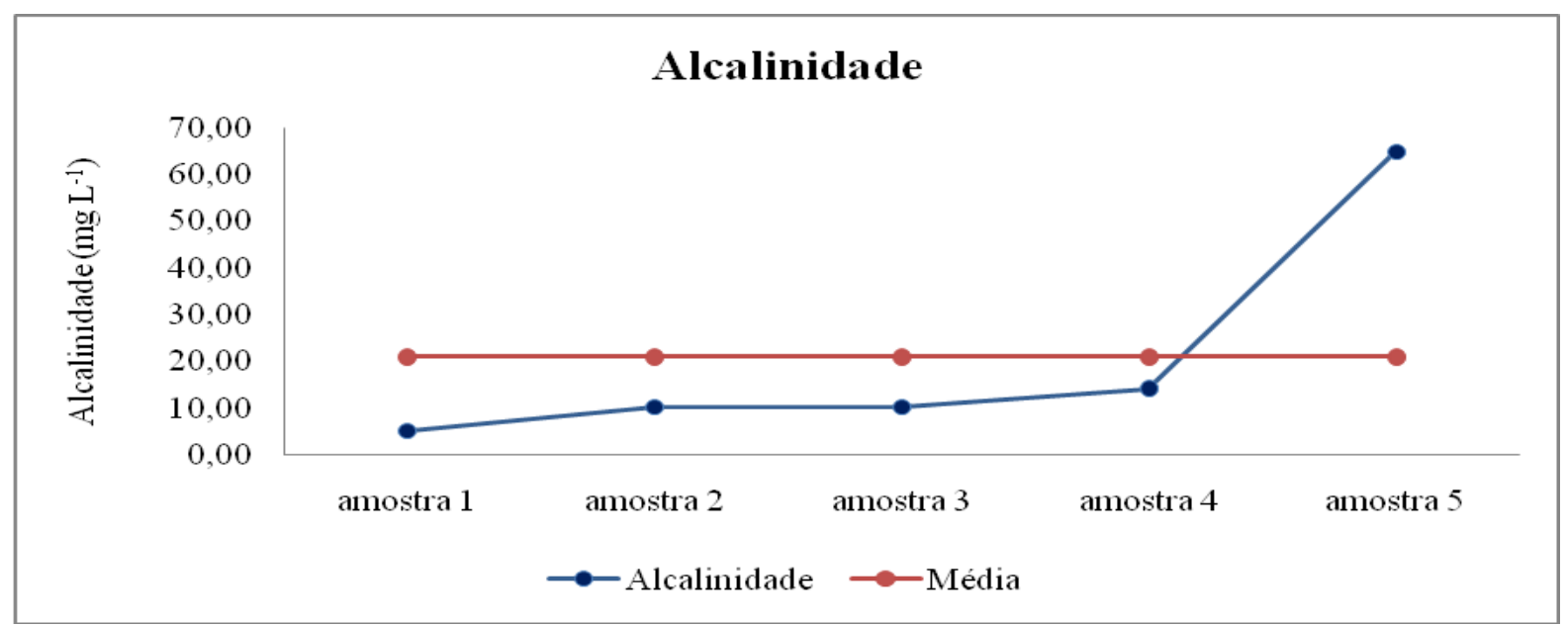

Figura 5 - Valores médios de Alcalinidade obtidos nas análises da água do Córrego dos Cesários Anápolis/GO

\subsection{4 - Dissolução de substâncias -Cátions e Ânions}

A presença principalmente de cálcio e magnésio, e em menor escala de ferro, alumínio e outros cátions, associados a ânions como carbonato (mais propriamente bicarbonato, que é mais solúvel), nitrato, silicato, cloreto e sulfato, conferem um certo grau 
de dureza à água impedindo a precipitação de sabão e transformando-os em complexos insolúveis, não formando espuma até que o processo se esgote. Perpetuo (2009), afirma que:

Nas águas naturais, a dureza é uma condição importante, por formar complexos com outros compostos, modificando seus efeitos sobre os constituintes daquele ecossistema. Por isso, a dureza é um parâmetro tradicionalmente utilizado no controle de bioensaios de avaliação de toxicidade de substâncias ou de efluentes.

A Tabela 1 quantifica esses parâmetros e os compara com os limites estabelecidos pela Resolução CONAMA 357/2005.

Tabela 1 - Quantificação de cátions e anions nas amostras de água do Córrego dos Cesários

\begin{tabular}{|c|c|c|c|c|c|c|c|}
\hline Parâmetros & $\begin{array}{l}\text { CONAMA } \\
357 / 2005\end{array}$ & $\begin{array}{c}\text { Amostra } \\
1\end{array}$ & $\begin{array}{c}\text { Amostra } \\
2\end{array}$ & $\begin{array}{c}\text { Amostra } \\
3\end{array}$ & $\begin{array}{c}\text { Amostra } \\
4\end{array}$ & $\begin{array}{c}\text { Amostra } \\
5\end{array}$ & LQ \\
\hline Cálcio & $\mathrm{ND} \mathrm{mg} \mathrm{L^{-1 }}$ & 1,30 & 3,40 & 2,10 & 2,90 & 12,7 & 0,10 \\
\hline Magnésio & $\mathrm{ND} \mathrm{mg} \mathrm{L}^{-1}$ & 0,30 & 0,50 & 0,70 & 0,80 & 2,50 & 0,20 \\
\hline Ferro & $0,30 \mathrm{mg} \mathrm{L}^{-1}$ & $<L Q$ & $<L Q$ & $<L Q$ & 0,40 & $<L Q$ & 0,10 \\
\hline Alumínio & $0,10 \mathrm{mg} \mathrm{L}^{-1}$ & $<L Q$ & $<L Q$ & $<L Q$ & 0,30 & 0,20 & 0,10 \\
\hline Nitrato & $10,0 \mathrm{mg} \mathrm{L}^{-1}$ & 0,79 & 0,49 & 0,90 & 2,14 & 13,19 & ND \\
\hline Silício & $\mathrm{ND} \mathrm{mg} \mathrm{L}^{-1}$ & 1,90 & 2,00 & 2,20 & 3,00 & 3,90 & 0,30 \\
\hline Cloro & $0,01 \mathrm{mg} \mathrm{L}^{-1}$ & 0,75 & 0,51 & 0,71 & 1,28 & 10,95 & ND \\
\hline Sulfato & $250 \mathrm{mg} \mathrm{L}^{-1}$ & 0,72 & 4,06 & 1,24 & 1,38 & 6,39 & ND \\
\hline Nitrito & $1,00 \mathrm{mg} \mathrm{L}^{-1}$ & 0,00 & 0,39 & 0,07 & 0,08 & 3,77 & ND \\
\hline Sódio & ND mg L ${ }^{-1}$ & 0,72 & 0,67 & 0,94 & 2,07 & 14,00 & 0,001 \\
\hline Potássio & $\mathrm{ND} \mathrm{mg} \mathrm{L}^{-1}$ & 0,39 & 0,62 & 0,52 & 0,55 & 3,92 & 0,001 \\
\hline Flúor & $\begin{array}{l}1,40 \mathrm{mg} \mathrm{L}^{-1} \\
0,020 \mathrm{mg} \mathrm{L}^{-}\end{array}$ & 0,02 & 0,14 & 0,06 & 0,00 & 0,21 & ND \\
\hline${ }^{*}$ Fosfato & 1 & 0,00 & 0,00 & 0,00 & 0,00 & 0,00 & 0,00 \\
\hline
\end{tabular}

LQ - limite de quantificação.

ND: Não determinado

${ }^{*}$ Fósforo total (ambiente lêntico)

Analisando os resultados encontrados na Tabela 1 percebe-se uma acumulação crescente dos parâmetros em relação ao distanciamento da nascente em que foi realizada a coleta, com uma variação na amostra 2, o que pode ser justificada pelo encontro das águas da de lavagem de filtros com as águas da nascente, diluindo assim parte dos resíduos. 
Os parâmetros como o ferro, o nitrato e o nitrito ultrapassam em pelo menos uma amostra o limite estabelecido pela Resolução CONAMA/2005. As concentrações de ferro, nitrato e nitrito obtidos nas análises realizadas encontram-se fora do limite de $0,3 \mathrm{mg} \mathrm{L}^{-1}$ para o ferro, $10,0 \mathrm{mg} \mathrm{L}^{-1}$ para o nitrato e $1,0 \mathrm{mg} \mathrm{L}^{-1}$ para o nitrito.

O ferro, apesar de não se constituir um tóxico, traz diversos problemas para o abastecimento público de água, como por exemplo, confere cor e sabor à água, provocando mancha em roupas e utensílios sanitários; também traz o problema do desenvolvimento de depósitos em canalizações e de ferrobactérias, ocasionando a contaminação biológica da água, na própria rede de distribuição.

Fontes de água contendo altas concentrações de nitrato apresentam um grande risco para a saúde pública e animal. O ânion não contém relativa toxidez para os adultos, entretanto, concentrações maiores que $10 \mathrm{mg} / \mathrm{L}$ de nitrato podem ser fatais para crianças menores de seis meses, causando uma doença chamada metahemoglobinemia infantil. Em crianças, nitrato é convertido a nitrito, que se combina com a hemoglobina no sangue, formando metamoglobina causando a síndrome do bebê azul. Também, outros problemas podem ser causados pela formação de nitrosaminas cancerígenas.

A contaminação ambiental pelo nitrato é resultado da sua lixiviação em solos, causada pelo uso de fertilizantes e também, efluentes urbanos podem contribuir com até $40 \%$ dos nitratos presentes em águas superficiais.

Em consideração ao cloro, este se encontra elevado e fora dos padrões estabelecidos pela Resolução CONAMA/2005 em todas as amostras coletadas. Devido ao seu forte poder oxidante o cloro é um excelente bactericida em soluções aquosas. Quando usado para tratar águas potáveis o cloro não apenas atua como bactericida, mas também suaviza os efeitos adversos do ferro, manganês, amônia e sulfetos

A resolução CONAMA 357/2005 estabelece limite de $0,1 \mathrm{mg} \mathrm{L}^{-1}$ de alumínio para corpos hídricos de classe 2, estando as concentrações apresentadas no presente estudo, acima deste valor. O aumento da concentração de alumínio está associado com o período de chuvas e, portanto, com a alta turbidez. Os demais parâmetros se enquadram dentro dos padrões exigidos pela legislação. 


\section{3 - CONSIDERAÇÕES FINAIS}

A contaminação da água está se tornando cada vez mais uma preocupação e um dos principais problemas enfrentados nos dias de hoje, ou seja, este recurso vem sendo poluído de tal maneira que já não se pode consumi-lo em seu estado natural. As pessoas utilizam a água não apenas para beber, mas também para se desfazer de todo tipo de material e sujeira.

Se as águas residuais forem para os rios e mares, as substâncias que elas transportam irão se acumulando e aumentam a contaminação geral das águas. Isto traz graves riscos para a sobrevivência dos organismos. Essa é uma das situações enfrentadas pelo Córrego dos Cesários em Anápolis/GO que recebe efluentes provenientes da Estação de Tratamento de Água e de esgotos no decorrer de seu curso.

As autoridades e a população em geral devem estar atentas a esse tipo de descaso e tomarem as devidas providências para evitar que continue o despejo de resíduos e, assim, evitar que surjam problemas maiores referentes à alteração da classe do rio como danos à saúde da população e outros tipos de contaminação do solo e proliferação de doenças.

\section{BIBLIOGRAFIA}

ANIDO, N.M.R. Caracterização hidrológica de uma microbacia experimental visando identificar indicadores de monitoramento ambiental. 200269 p. Dissertação (Mestrado em Recursos Florestais) - Escola Superior de Agricultura "Luis de Queiroz", Universidade de São Paulo, Piracicaba.

ARCOVA, F.C.S.; CICCO, V. Qualidade da água de microbacias com diferentes usos do solo na região de Cunha, Estado de São Paulo. Scientia Forestalis, n.56, p.125-134, dez. 1999.

APHA - AWWA. Standard methods for the examination of eater and wastewater, 19ed. Washington - USA: Public Health Association /American Water Works Association, Water Enviroment Federation, 2005. 
BRASIL, Ministério da Saúde. Vigilância e controle da qualidade da água para consumo humano" Brasília DF, 2006.

Carr, G.M. and J.P. Neary. (2008). Water Quality for Ecosystem and Human Health, 2nd Edition. United Nations Environment Programme Global Environment Monitoring System. Retrieved 14 July 2009.

CETESB. Variáveis de qualidade das águas. Disponível em: <http://www.cetesb.org.br>. Acesso em: 13 de FEVEREIRO de 2013.

CONAMA. Conselho Nacional do Meio Ambiente. Ministério do Meio Ambiente. Resolução n. 357 de 17 de março de 2005. Diário Oficial da União, Brasília, 2005. 23p. Estabelece normas e padrões para qualidade das águas, lançamentos de efluentes nos corpos receptores e dá outras providências.

PERPETUO, E. A. Parâmetros de caracterização da qualidade das águas e efluentes industriais. Lab. Microbiologia - CEPEMA-USP, 2009.

REBOUÇAS, A. C. Panorama da água doce no Brasil. In: REBOUÇAS, Aldo da Cunha (Org.). Panorama da degradação do ar, da água doce e da terra no Brasil. São Paulo: IEA/USP; Rio de Janeiro: Academia Brasileira de Ciências, 1997. p. 59-107.

SILVA, D. F. Variabilidade da qualidade de água na bacia hidrográfica do Río São Francisco e atividade antrópicas relacionadas. Qualit@s Revista Eletrônica ISSN 1677 4280 Vol.9. $\mathrm{N}^{\circ} 3,2010$.

SHINMA, E.A. Avaliação da qualidade das águas dos rios da Bacia Hidrográfica do Alto Paraguai - Pantanal. Dissertação (Mestrado em Tecnologias Ambientais) Universidade Federal do Mato Grosso do Sul, UFMS, 2004. 91p. 
SÉ, J. Monjolinho e sua bacia hidrográfica com entregadores de sistemas ecológicos: um conjunto de informações para o início de um processo de pesquisa ecológica de educação, planejamento e gerenciamento ambientais a longo prazo. Dissertação (Mestrado) Escola de Engenharia de São Carlos, Universidade de São Paulo, 1992. 